\title{
RESEÑAS
}

\section{UN GRABADO PRECIOSISTA DE CARPENTIER}

A mediados del año pasado apareció en México la novela El recurso del método, de Alejo Carpentier; con esta obra, que despertó admiración pero también polémicas y críticas adversas (en ella el escritor cubano confirmaba virtudes al tiempo que ensayaba renovarse y refrescar su visión estética, lo que provocó reacciones diversasl), el autor sellaba un período de once años de silencio novelístico. De silencio, no de inactividad, porque simultáneamente Carpentier anunciaba que tenía otra novela terminada y una más, muy avanzada en su proceso ${ }^{2}$. Justo en noviembre de 1974, a modo de homenaje al escritor por su setenta aniversario, apareció la primera de las prometidas: Concierto barroco ${ }^{3}$, en una muy hermosa edición ilustrada.

Aunque la palabra "novela" campea con curiosa insistencia en varias partes del libro (en la carátula, en la portada, en la contratapa), el lector descubrirá muy pronto que este Concierto no es ninguna de esas caudalosas y proliferantes narraciones mayores del arte carpentèriano. y que es incluso más breve que su novela corta El acoso: apenas ochenta y dos páginas de tipo grande, con amplísimos márgenes y numerosas viñetas y dibujos, corresponden mejor a las dimensiones habituales de una nouvelle. Pero si la extensión (elemento en todo caso no muy importante) justifica otorgarle esa categoría, menos fácil resultará si se atiende a su estructura; por lo menos, no ha sido fácil para mí. La anécdota es minima y apenas da para un desarrollo dramático y menos para jugar con un enredo. De hecho, no hay bistoria sino una ilustración, un cuadro de época captado en todo su esplendor y montado sobre un dato erudito, no sobre una vivencia real o imaginada; el Concierto barroco de Carpentier se parece a las viñetas y grabados que lo adornan: una vista fija, pomposa, perfecta, con la que el investigadór curioso se satisface como escritor.

Como se sabe, Carpentier es, aparte de novelista, un eminente musicólogo. (La música en Cuba es un monumento de consulta obligada para los especialistas.) Los lectores de sus relatos saben además cómo esas preocupaciones y conocimientos musicales pasan a su obra de imaginación, cómo la enriquecen, cómo se integran admirablemente a ella. Concierto barroco es algo distinto: es directamente un tributo a la música, una celebración de la pasión favorita del autor. En realidad, el texto es el resultado de un hallazgo personal de Carpentier que seguramente tiene importantes repercusiones en el mundo musical ; el de la ópera Moctezuma de Vivaldi, estrenada en Venecia en 1733, o sea "dos años antes de que Rameau escribiera Las indias galantes, de ambiente fantasiosamente incaico"' (p. 92), anota el escritor. El descubrimiento de esa obra desconocida del maestro barroco (que Carpentier documenta en el apéndice, con el facsímil del programa de estreno y una nota erudita) debió convocar en él otras imágenes queridas y consabidas: la dorada fascinación del siglo XVIII, la realidad americana interpretada por ( $\mathrm{y}$ trasvasada a) la cultura europea, el engarce del arte con la historia y de la imaginación con el

1 Véanse la extensa nota de Angel Rama ("Alejo Carpentier: un culto racionalista en el desenfreno tropical", La cultura en México, Suplemento de Siempre!, No. 654, agosto 21,1974 , p. VII-X) y la resefia de José de la Colina ("El recurso del método de El recurso del método", Plural, No. 35, agosto 1974, p. 76-78), ésta última réplica a la muy elogiosa nota de José Emilio Pacheco ("Vous êtes tous des sauvages'”, Plural, No. 33, junio 1974, p. $74-76$ ).

2 Reportaje reproducido en Casa de las Américas, No. 81, noviembre-diciembre 1973, p. 148-149.

3 (México: Siglo XXI Editores), 1974, 92 pp. 
pretigioso pasado, etc. Sólo Carpentier podía interesarse en un tema como éste, sólo Carpentier podía intentar un relato a partir de él: todo en el texto-información, concepción, simbolos, metáforas, sonidos y juegos verbales-es inconfundiblemente suyo.

Dos personajes americanos dominan la primera mitad de la obra: un rico y culto indiano de México y su criado negro, Filomeno. Los motivos carpenterianos empiezan a rotar: la escena primera describe, con exaltada profusión de detalles, la partida del Amo, iniciación narrativa que encontramos en cuentos como " Semejante a la noche" o en novelas como Los pasos perdidos. El motivo del viaje se enlaza también aquí, como en El siglo de las luces, con el de la tormenta agorera y la peste: "Desde la salida de la Veracruz habian caido sobre la nave todos los cientos encontrados que, en los mapas alegóricos, hinchan los carrillos de genios perversos, enemigos de la gente de mar. Con las velas rotas y averías en el casco, maltrecha la crujía, habiase llegado, por fin, a buen puerto, para encontrar La Habana enlutada por una tremenda epidemia de fiebres malignas'" (p. 17). Más tarde, el Amo sufre en Madrid la misma decepción de España ("triste, deslucida y pobre le parecía esa ciudad, después de haber crecido entre las platas y tezontles de México", p. 27) que sufre el indiano protagonista del cuento "El camino de Santiago", como síntoma de su descolocamiento histórico y cultural. Esa nostalgia americana aún persiste cuando el indiano llega a Venecia, centro físico del relato, pues su disfraz carnavalesco es precisamente el de Montezuma, y hasta por dos veces (p. 38 y 55) evocará burlonamente las calveras con las que juegan "los chamacos mexicanos en día de Fieles Difuntos". Pero ya esta escena veneciana, pintada con mano maestra, incluye a tres enmascarados cuya identidad descubriremos al comenzar la segunda mitad del relato (cap. V): "el joven napolitano, discípulo de Gasparini"' es Doménico Scarlatti, "el sajón" Jorge Federico es Haendel, y el "Fraile Pelirrojo" es Antonio Vivaldi. Estamos ahora en medio del reino de la música.

Creando o recreando un encuentro que pudo ser real (los tres grandes músicos fueron contemporáneos: Haendel viajó a Italia en 1706 y en 1709 conoció a Scarlatti en Venecia, donde campeaba el arte y el influjo de Vivaldi), Carpentier construye minuciosamente las tres escenas cumbres de este esfuerzo narrativo: la de los músicos en el Ospedale della Pietá, lugar que tiene algo de teatro, de escuela de música y de centro refinadamente erótico; la del trío, ya bastante ebrio, en el cementerio, que evoca el culteranismo de los temas de conversación de la novela pastoril y las insinuaciones de una novela licenciosa del siglo XVIII; y la del estreno de la ópera misma de Vivaldi, comentada ilustradísimamente por el indiano y su criado (ahora tan musicólogo como él), gracias a lo cual nos enteramos del largo tránsito de la historia de Montezuma, desde una crónica española hasta el maestro veneciano, y de las simpáticas arbitrariedades históricas (un militar azteca convertido en mujer, por ejemplo) del libreto. El más brillante de estos tres cuadros es el primero: un delicioso y vivaz cromo de una Venecia entregada a una orgía de los sentidos y a una sutil intoxicación del espíritu; y el menos logrado es justamente el último, que debía ser la cúspide del relato, quizá porque lo asfixia la información musicológica y el debate abstruso, pedantesco. Que, por ejemplo, un esclavo negro del Caribe discuta con Vivaldi no me parece irreal (como parece irreal que Vivaldi compusiese una obra sobre tema mexicano). El arte de Carpentier no es realista, sino alegórico, casi emblemático: sus personajes son figuras arquetípicas de una construcción literaria que debe flotar como un espacio sobre el espacio real; pero a veces, como aquí, la carga informativa, el dato culto y preciosista rasga esa ficción alegórica y la resiente por exceso: la verosimilitud interna del texto y la credulidad del lector se suspenden, y el encanto narrativo desaparece.

A partir del cap. VI otro motivo carpenteriano viene a sumarse al relato y a darle la típica resonancia filosófica que siempre tienen sus creaciones: la problemática del tiempo. Aunque cada rincón de los cuadros está diseñado con un rigor casi fanático, de pronto caemos en el anacronismo total: oimos a Vivaldi opinar sobre Stravinsky ("Buen músico, pero muy anticuado, a veces, en sus propósitos", p. 53) y al negro Filomeno hablar de una "jam session" (p. 54), lo que confirma en qué nivel de representación artística estamos. El capítulo final es, casi todo él, una reflexión sobre el tiempo y, a partir de eso, sobre la dialéctica América/Europa y la visión utópica, revolucionaria, como destino de nuestro continente. $\mathrm{El}$ indiano y Filomeno son los personajes puente que permiten esos vertiginosos sincretismos de los movimientos culturales. El amo siente otra vez la invencible nostalgia de la lejana A mérica ("de pronto, me sentí como fuera de situación, exótico en este lugar, fuera de sitio, lejos de mí mismo de cuanto es realmente mio...A veces es necesario alejarse de las cosas, poner un mar de por medio, para ver las cosas de cerca" , p. 76) y descubre la fascinación de lo fabuloso americano porque "todo futuro es fabuloso" (p. 77), mientras el siervo salta literalmente del siglo XVIII al llamado del spiritual, del Go down Moses en la tompeta de Louis Armstrong, y cae en esta época, dispuesto a volver a América, para hacer la revolución. El concierto barroco termina prefigu rando una nueva confusión (un nuevo concierto) de razas, pueblos y tiempos: lo anacrónico se vuelve sincrónico.

He disfrutado este texto, más que como una narración, como un muestrario del estilo y las constantes de 
Carpentier; el placer que brinda es frío, casi geométrico. Ya un sector de la critica ${ }^{4}$ ha insinuado que el acostumbrado "barroco" al que se afilia a Carpentier es más bien un estilo que se acerca al neoclásico, entre el rococó y el neoclásico, diría yo: en medio de las volüas y los pámpanos verbales que teje el artífice, siempre vela la diosa Razón. Paradójicamente, Concierto barroco confirma la verdadera naturaleza artística del escritor cubano.

Indiana University, Bloomington

JOSE MIGUEL OVIEDO

JOSE R, BRENE, Fray Sabino, La Habana: UNEAC, 1971.

Debido a las dificultades en obtener libros de Cuba, con mucho retraso llega a mis manos la comedia de José R, Brene, Fray Sabino, premio de teatro de la Unión Nacional de Escritores y Artistas de Cuba, 1970 y publicada en 1971. No estoy enterado de ninguna reseña hasta la fecha; lo cual no me sorprende, dadas las dificultades ya mencionadas, además del poco conocimiento fuera de Cuba de la obra de Brene. La pieza, sin embargo, se merece una mayor publicidad y estudio por parte de la critica; en particular, en lo referente a su temática.

La temática de Fray Sabino se compone de tres aspectos principales -- los temas de (1) la redención del hombre, (2) el egoismo que lo mantiene socialmente retrasado y (3) la tragedia inherente en la existencia humana: la muerte. Brene logra manejar esta triple temática muy efectivanente, aunque -- como veremos más adelante -- el planteamiento final resulta algo inapropiado, o al menos desconcertante, para el público de Cuba revolucionaria.

A primera vista, el tema de la redención del hombre parece ser el más importante. De hecho en Fray Sabino observamos tres redentores: Jesucristo, Fray Sabino y Pancho Majagua, todos los cuales aparecen como personajes de la pieza. Naturalmente que -- como ya lo indica el titulo -- Brene se ha dedicado a caracterizar más a fondo la personalidad de Fray Sabino. Este, pobre cura de la no menos pobre parroquia de Candonga, se nos manifiesta como un nuevo Cristo, empenado él en echarse encima todos los pecados del pequefio pueblo. Lo sorprendente, no obstante esta pretensión de santidad, es que Fray Sabino no vacila en robar, violar y asesinar, con tal de evitar que sus feligreses cometan pecados similares. Pero esta nueva versión de Nazarín no termina ahi, sino que incluso, al final, el sacerdote se ha convertido en una especie de verdugo que aplica la pena de muerte a los pecadores de Candonga.

Como dije anteriormente, en la comedia hay otros redentores; de un lado, Jesucristo, con su mensaje tradicional de salvación, mermado por una unión inmoral entre la iglesia y el gobierno municipal, y por otro lado, frente a tal corrupción, Brene nos presenta la figura revolucionaria de Pancho Majagua, hombre que, como su apelativo delata, 1 es un hijo del pueblo y uno de los pocos personajes positivos de la obra. ${ }^{2}$ Con todo, su personalidad no está completamente delineada, ya que Brene lo mantiene marginado de la acción central. Además, la esperanza que este redentor ofrece pronto se pierde debido a su fracaso, por motivo de una delación. En efecto, los tres redentores fracasan irremediablemente, aunque en el caso de Pancho Majagua sea por razones fuera de su alcance.

En Candonga no hay redención posible y el autor nos lo asegura a través del segundo tema de Fray Sabino: el egoísmo. Casi todas las personas en Candonga se mueven impulsadas por este resorte. Este es el verdadero motivo de la "santidad" de Fray Sabino: en el fondo él desea ser otro Dios, con pleno poder sobre sus criaturas. Al mismo tiempo, el comportamiento de. Fray Sabino determina que Jesucristo y su iglesia se sientan celosos de este nuevo Mesías, que poco a poco se va convirtiendo en una amenaza para Su Santidad. Egoistas también son el Alcalde (dinero), la Alcaldesa, el Obispo, el Sargento $1^{\circ}$ y el Sargento $2^{\circ}$ (los placeres de la carne), y el hijo ilegítimo de Fray Sabino -- Brene lo ha nombrado Jesús -- que hace posible la delación de Pancho Majagua, porque necesita el dinero de la recompensa para sus estudios.

4 Véase particularmente Emir Rodríguez Monegal en El arte de narrar (Caracas, Morte A vila, 1968), pp. 286288. También Ida Vitale ("La exaltación de un camino americano para la música y las demás artes', Diorama de la Cultura, Suplemento de Excelsior, enero 12,1975, p. 14) ha señalado que "ni el Conciento barroco es barroco, ni creo que lo sea necesariamente Carpentier ; (está) más próximo en todo caso a los esquemas manieristas".

${ }^{1}$ Majagua es una palabra de origen taíno que designa un árbol malváceo, muy común en los terrenos anegadizos de Cuba y las demás Grandes Antillas. Su madera es verdosa y extremadamente dura. De aqui que el nombre de Pancho Majagua significa un hombre de pelo en pecho.

2 No obstante, Pancho Majagua comete la infracción moral de prometerle a Fray Sabino un ministerio en recompensa por su ayuda.. (43). 